\title{
Human Capital Training Management
}

\author{
Melly Suziani \\ Non-Formal Education Department \\ Postgraduate School, Indonesia University of Education \\ Bandung, Indonesia \\ melsuziani@student.upi.edu
}

\begin{abstract}
Human resorces development is an important in the corporation . Employee training is a form of lifelong education effort undertaken by a company to continuously update its employees' knowledge and skills. This article describes the management of employee training conducted by the PT Kereta Api Indonesia, using qualitative methods The training program was systematically arranged from the planning phase, the implementation phase, and the evaluation phase. Training is essentially a united system where each component is equally important as each has its own function. Human capital training is done according to the need of participants and the institution, so it can be meaningful training in the end. An effective training management will bring about the improvement in the employees' knowledge and skills.
\end{abstract}

Keywords- Training and development, human capital, training management

\section{INTRODUCTION}

Human resource becomes one of the key factors in determining the successful operation of a corporation. Human resources include staffs and employees. Employees' performance determines the sustainability of the corporation. Thus, companies are always encouraged to develop the quality of their human resources. Training is the effort chosen by many corporations and other organizations in Indonesia, not to mention PT. Kereta Api Indonesia, to develop their human resources.

Training and development is a form of lifelong learning held by PT. Kereta Api Indonesia to maintain and improve the quality of its employees. The broader the knowledge, the greater the job performance. Dragomiroiu, Hurloiu, \& Mihai highlight, "if the knowledge that employees possess is good for the organization, the logical solution seems to be: to give the employees the opportunity to gain as much knowledge" [1].

However, training cannot necessarily improve employees' performance. Training managerial plays the biggest role. How the training is developed should be started from identifying the problem, setting the goals and objectives, developing the materials, selecting the trainers, choosing the venue of the training, implementing it and also evaluating the training and should be arranged into a united model of training.

There are some studies related to the development of human resources. Babes-Bolyai University developed training for managers with failure authority stories [2]. In 2015, Department of Management Studies, Indiana Institute of Technology Roorkee reviewed the integrated model which was developed by highlighting the relationship between the perception of accessibility to training, support for training perception, the perception of the benefits of training, and the implications of training on the quality of mediation services through organizational commitment [3].

Some universities in Italy conducted a study on training and concluded that training is essential for human resources in promoting and expanding lifelong learning [4]. Hawaiian university developed a cross cultural education and training program [5]. The other related studies in references [6] to [9] also elaborated the same issue regarding human resources development training. Overall, training as a crucial program for human resources development needs a proper management. In its implementation, the administrative should consider the training principles [9]. Thus, this article shows how the human capital training management that has been done at PT KAI to improve the employee performance.

\section{METHOD}

This study took place at the Managerial Training Center PT. KAI Indonesia. This study aimed to observe the training management at the Managerial Training Center. The researcher employed qualitative method to collect the data. The study focused on the training management which influence the employees' performance at PT KAI Indonesia, in this case, the managerial employees.

Fundamentally, this research tried to disclose how the training management model was carried out by PT. Kereta Api Indonesia. The data was gathered through an interview, engaging the training managerial at the Managerial Training Center PT. KAI. The data was analyzed by comparing the results of empirical study with that of theoretical study. This 
research referred to the data of the interview results on the training management process.

\section{RESULTS}

The results of the study on the training management process at the Managerial Training Center PT. Kereta Api Indonesia consisted of planning phase, implementation phase, and evaluation phase. In the needs analysis identification, the cooperation among HRD Division, users, and Training Development Division was required. The planning stage was begun with the training needs identification. The orientations covered the employee needs and the corporation needs. The orientation of employee needs is an identification made by the User to meet the needs of employees in performing their duty. The user was responsible for identifying employees' potential and qualification in performing their jobs. On the other hand, the orientation of corporation needs was conducted by the HRD Division. In this phase, HRD Division identified the needs for the growth of the corporation.

The stages of the training held by the Managerial Training Center PT. KAI were begun from the training needs analysis based on what Simamora (1995) states, "Training needs assessment is the most important stage in developing a training program" [11]. The same notion is also pointed out in several studies as follows, "In implementing a training program for adult workers, it is important to incorporate basic, well-known principles of adult learning. Among other thing these principles emphasize that adult want the content of their training to be relevant to their jobs and need training content and that processes that build own their experiences and knowledge." [12]

The researcher also found that training needs assessment process in the training center also in line with experts' statement as follows, "The decision of training needs analysis requires three types of analysis, namely organizational analysis, operational analysis and personnel analysis" [13]. Additionally, the researcher also found that the following thing related to the training needs analysis: the corporation has assessed the training needs of their employees, because this organization already identified parts of the organization which need training. Furthermore, the training needs assessment have been analyzed by the corporation to determine the goals and objectives of the organization.

Based on the needs analysis, it was found that there were some employees who were encouraged to join Human Capital Training. So, the corporation expected to the employees who joined the training to widen their knowledge and their skills in order to perform their new duty at best. Besides, the organization has conducted the personnel analysis where the user held a needs assessment at the individual level to determine who needed training and what training was needed.
The Managerial Training Center PT. KAI applied deductive approach during the needs analysis stage since this approach allowed the administrative to identify the training needs in general involving a broader scope. When establishing the training needs to the trainees who have the same characteristics, these trainees would be offered some aspects to be considered together. It was assumed that the results of the identification applied to all trainees who owned similar characteristics.

In the aspect of training design, the respondents stated that the general purpose of the implementation of this training was to improve their knowledge and abilities in the administrative skills. The decision of training material was prepared in such a way that the results of the training can be applied when the employees returns to their workplace. Based on the respondents' statements, the training was held for 3 weeks or 16 weekdays and consisted of theories and practices. Besides, experts from management field were also invited to give insight to the trainees so that they could join the training effectively as the trainers or experts disseminate the materials from the syllabus using the principles inherent with the andragogical approach for adult learners

The design of the training conducted by the Managerial Training Center PT. KAI was in line with what Simamora identifies as the eight phases of training as follows: 1) needs assessment and human resources assessment for training; 2) identification of training targets; 3) setting the criteria; 4) administering a pre-test to the trainees; 5) selecting the appropriate and suitable training technique and learning principles; 6) implementing the training; 7) observing the implementation; and 8) comparing the results of the training with the predetermined criteria [15].

The selection of the methods and techniques was based on the consideration that this training was intended to encourage, foster interest in learning, create a conducive learning climate, promote creativity, encourage reflective learning, as well as encourage the trainees to overcome their lacks in learning [16]. In line with this notion, the selection of the suitable training method was very crucial in helping the training achieve the goals. From the description of the research findings, it was revealed that the methods and techniques in the Human Capital training were in the form of discussions, lectures, discussion, and case studies. According to the respondents' statements, the training strategies implemented in the teaching and learning process during the training were classical strategies such as teacher centered-approach and student centeredapproach, human resource business processes, recruitment, pension mutation, text layout, disciplinary punishment, pay role, organization, reward and punishment and assessment.

According to the statement of the managerial of the training as well as the trainees, the recruitment 
process of the trainees was held in line with the recruitment procedure conducted by the users in which the candidates of the trainees were invited by the HRD Division and they had to follow the administrative procedures determined by the training executives. Recruitment of training participants can be the key that could determine the success of the next phases of the training. In this recruitment process, the administrative set several requirements that must be fulfilled by the participants, particularly related to the characteristics of participants who had possibility to attend such training [17].

Kamil (2010: 19) points out, "evaluation of a training program is an activity to assess the entire training from the beginning to the end, and the result becomes the input for the development of further training".

From the description of the research findings regarding the evaluation of the training, respondents noted that the aspects of evaluation were the trainees' understanding of the training materials, the implementation of the training, and the evaluation of the alumni who were rated by the users. The evaluated components were the trainees (attendance, attitudes, knowledge and behaviours) who were assessed through a pre-test and a post-test, the implementation of the training (process and results), facilities (services, facilities, and readiness) and impact evaluation (conducted by the users to assess the alumni's performance). The evaluation instrument used in the evaluation process of this training was an instrument distributed by the committee, which assessed each component from the beginning of the training until the last day of training implementation.

It was observed that the stages of the evaluation process conducted by the Managerial Training Center PT. KAI were in line with the theory of "The Four Level Techniques Evaluation Training" stated by Kirkpatrick. The evaluation describes the four stages in the evaluation process, namely reaction, learning, behaviour and result.

Reaction. It is defined as a reaction or response of the trainees in a training program. How well the trainees liked the training program measures the participants' level of satisfaction. Assessment at this level is also determined by several indicators, including the instructor during training implementation, training facilities, training schedules, instructional media, training materials, beverages and meals, assignments, case studies, handouts in the learning process.

Learning. At this second level, the evaluation process aims to measure the trainees' level of understanding of training materials. The evaluation instruments are pre-test and post-test. At this level trainer is the key factor in the evaluation process, why is that? This is because the trainer is the source of information during the transformation process of knowledge and skills to the trainees.
Behaviour. At this third level of evaluation, the assessment covers how significant the changes of the trainees' attitudes when they return to their workplace after completing the training program.

Result. This fourth level in the evaluation process assesses the impact of the training program to the organization or corporation. At this level, the assessment is conducted covering the improvement in the quality and the quantity of work.

The general model of training management at the Managerial Training Center PT. Kereta Api Indonesia can be seen in Figure 1.

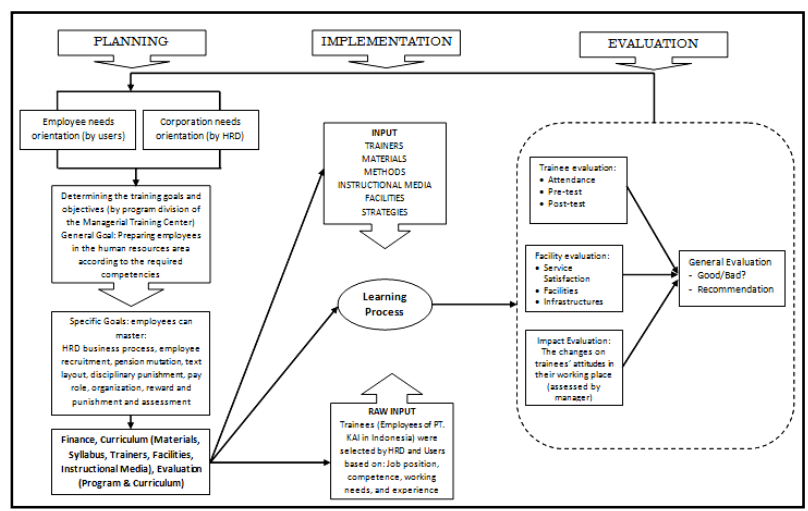

Fig. 1. Human Capital Training Model of the Managerial Training Center PT. KAI

\section{CONCLUSION}

The training management at the Managerial Training Center PT. KAI was designed in such a way by the managerial in order to develop its employees' performance.

The training was developed based on the results of needs analysis of the employees and the corporation so that the training would give significant benefits to both the employees and the corporation. The training program was began with needs analysis, setting the goals and objectives, selecting the training participants, deciding the media, trainers, methods, learning facilities and learning materials, and developing the evaluation instruments.

The training management at the Managerial Training Center PT. KAI was categorized 'good'. It could be seen from the gradual improvement on the quality of the training management which did not only please the employees but also increase their motivation to reach the optimal performance.

\section{ACKNOWLEDGMENT}

The writer would like to express her special thanks of gratitude to Non-formal Education Department, Postgraduate School Indonesia University of Education which has given the golden opportunity to contribute in this research. 


\section{REFERENCES}

[1] Dragomiroiu, R., Hurloiu, I.-I., \& Mihai, G. (2014). Induction Staff Training. Procedia Economics and Finance, 16(May), 368-373.

[2] Avni, M. (2015). Training Processes for Failing Local Authority Managers in the Arab Sector in Israel. Procedia Social and Behavioural Sciences, 209(July), 73-77.

[3] Dhar, R. L. (2015). Service quality and the training of employees: The mediating role of organizational commitment. Tourism Management, 46, 419-430.

[4] Aleandri, G., \& Refrigeri, L. (2014). Lifelong Education and Training of Teacher and Development of Human Capital. Procedia - Social and Behavioral Sciences, 136, 542-548.

[5] Stephan, W. G., \& Stephan, C. W. (2013). Designing intercultural education and training programs: An evidencebased approach. International Journal of Intercultural Relations, 37(3), 277-286.

[6] Yi, L., Marais, K. B., \& Zhang, S. G. (2014). Conceptual modelling of training and organizational risk dynamics. Procedia Engineering, 80, 313-328.

[7] Frese, M., Hass, L., \& Friedrich, C. (2016). Personal initiative training for small business owners. Journal of Business Venturing Insights, 5, 27-36.
[8] Lee-Kelley, L., \& Blackman, D. (2012). Project training evaluation: Reshaping boundary objects and assumptions. International Journal of Project Management, 30(1), 73-82.

[9] Alcivar, I., \& Abad, A. G. (2016). Design and evaluation of a gamified system for ERP training. Computers in Human Behaviour, 58, 109-118.

[10] Chong, T. A., \& Duane, Tway, C. (2006). Elements and Principles of Training as a Performance Improvement Solution. Performance Improvement, 45(3), 28-32.

[11] Simamora, H. (1995). Manajemen Sumber Daya Manusia. Yogyakarta: Sekolah Tinggi Ilmu Ekonomi YKPN.

[12] Chong, T. A., \& Duane, Tway, C. (2006). Elements and Principles of Training as a Performance Improvement Solution. Performance Improvement, 45(3), 28-32.

[13] Simamora, H. (1995). Manajemen Sumber Daya Manusia. Yogyakarta:Sekolah Tinggi Ilmu Ekonomi YKPN

[14] Kamil, M. (2003). Model-Model Pelatihan.

[15] Simamora, H. (1995). Manajemen Sumber Daya Manusia. Yogyakarta: Sekolah Tinggi Ilmu Ekonomi YKPN.

[16] Abdulhak, Ishak. (2000). Metodelogi Pembelajaran Orang Dewasa. Bandung: CV Andira.

[17] Kamil, M. (2012). Model Pendidikan dan Pelatihan (Konsep dan Aplikasi). Bandung: Alfabeta. 